Anahit Manasyan

ORCID: 0000-0001-6404-4318

\title{
The Issues of Differentiation of Constitutional Policy from Ongoing Politics
}

KEY WORDS:

constitutional policy, ongoing politics, Constitution, constitutional stability, symbol of a constitutional system

\section{Introduction}

Many authors believe that constitutional policy thoroughly depends on the ongoing politics. According to them constitutions are subject to political actors and events, exist only during such a timeframe and define just such regulations, within which they are expedient from the political point of view. We believe that such a perception needs to be overcome and rethought. Hence, the differentiation of constitutional policy from ongoing politics is one of the most important issues of the modern legal and political thought and needs complex and thorough analysis.

\section{The Impact of Politics on Constitutional Developments}

A rich intellectual tradition in political science postulates that formal institutions emerge and change as a byproduct of political and social change. The view expressed in literature, according to which the significance of the Constitution is in the fact that it is the real prize of the political struggle, is not accidental ${ }^{1}$. In this

1 See R. Calvert, Coordination and Constitutional Change, Washington University in St. Louis, p. 11, http://calvert.wustl.edu/downloads/CoordConstChg.MPSA.pdf (access: 15.04.2016); Overview of Law and Politics, [in:] R. Goodin (ed.), The Oxford Handbook 
perspective, political actors support a constitution in equilibrium only as long as the underlying configuration of interests and powers that sustains the equilibrium remains stable. Should the interests or resources of powerful actors change, so would the existing constitutional structure ${ }^{2}$. Moreover, the approach that, constitutions are subject to political actors and events and exist just during such a timeframe, within which they are expedient from the political point of view, and no more, has been widely spread ${ }^{3}$. Hence, the important changes of the political and social life increase also the risk of the amendment of the Constitution.

Various research show that the stability of modern constitutions mostly depends on political stability, and the interruption of the balance of the state power in the result of armed upheavals, revolutions, etc. have the greatest impact on decreasing the viability of the Constitution. For example, $66 \%$ of the constitutions of the Latin American countries, which lost their effect in 1946-2000, were replaced just during these events ${ }^{4}$.

In this context the view expressed in literature is worth mentioning, according to which the Constitution has a mixed - political-legal character, hence, the political and legal are closely interrelated within the frames of the Constitution 5 . Moreover, several authors state that constitutionalism is the factual realization of politics expressed in the content of the Constitution ${ }^{6}$. Taking this into consideration, the key elements of the essence of the Constitution are formulated in the form of the following questions: 1 . The will of which political forces has been defined in the Constitution? 2. The interests of which social layers are expressed in constitutional provisions and preserved by them? etc. ${ }^{7}$. According to a number of authors, law cannot exist without politics, as politics gives the law its driving force and its "rough content" or substance, which law then adapts to its autonomous framework and develops its final form, expressing it in a specific normative manner ${ }^{8}$.

of Political Science, 2011, http://www.oxfordhandbooks.com/view/10.1093/oxfordhb/ 9780199604456.001.0001/oxfordhb-9780199604456-e-012?print=pdf, (access: 16.06.2018).

2 See G. L. Negretto, The Durability of Constitutions in Changing Environments: A Study on Constitutional Stability in Latin America, http://verfassungswandel.files.wordpress. com/2008/10/14-negretto-paper.pdf (access: 15.04.2016).

3 D. Oliver, C. Fusaro (eds.), How Constitutions Change (A Comparative Study), Oxford and Portland, Oregon, 2011, p. 115.

4 See G.L. Negretto, The Durability of Constitutions in Changing Environments: A Study on Constitutional Stability in Latin America, http://verfassungswandel.files.wordpress. com/2008/10/14-negretto-paper.pdf (access: 15.04.2016).

5 Sее И. А. Кравец, Российский конституционализм: проблемы становления, развития и осуществления, Санкт-Петербург 2005, p. 148; D. Oliver, C. Fusaro (eds.), How Constitutions Change..., p. 242.

6 Seе Н. Витрук, Конституциионоое правосудие, Москва 2005, p. 144.

7 Seе И. А. Кравец, Российский конституционализм ..., p. 154-155.

8 See M. Cerar, The Relationship Between Law and Politics, «Annual Survey of International \& Comparative Law» 2009, Volume 15, Issue 1, p. 33. 
We also believe that from the viewpoint of the discussed issue politics is an important factor, as the political environment has an undeniable impact on the choice of constitutional solutions and their factual realization. The reason for such a conclusion is obvious, as in almost all modern constitutional systems constitutions are adopted and amended in the result of direct participation of political forces, notwithstanding the fact whether the constitutional regulations are adopted by the parliament ${ }^{9}$, special body established for this $\operatorname{aim}^{10}$, or the people ${ }^{11}$.

For instance, Article 202 of the RA Constitution defines that the Constitution and amendments to Chapters $1-3,7,10$ and 15 of the Constitution, as well as to Article 88, to the first sentence of part 3 of Article 89, to part 1 of Article 90, to part 2 of Article 103, to Articles 108, 115, 119-120, 123-125, 146, 149 and 155, and to part 4 of Article 200 of the Constitution shall be adopted only through a referendum. At least one third of the total number of Deputies, the Government or two hundred thousand citizens having the right of suffrage shall have the right to the initiative of adopting or amending the Constitution. The National Assembly shall adopt the decision on putting the draft to referendum by at least two thirds of votes of the total number of Deputies. Except for the specified Articles, amendments to other Articles of the Constitution shall be adopted by the National Assembly, by at least two thirds of votes of the total number of Deputies. At least one fourth of the total number of Deputies, the Government or one hundred fifty thousand citizens having the right of suffrage shall have the right to corresponding initiative. In case the National Assembly does not adopt the draft of the amendments to the Constitution provided for in part 2 of the mentioned article, it may be put to referendum upon the decision adopted by at least three fifths of votes of the total number of Deputies. Moreover, according to Article 206 of the RA Constitution the President of the Republic shall call a referendum within a period of three days following the adoption by the National Assembly of a decision on holding a referendum.

It should also be noted that the essence of the constitutional regulations itself presupposes that their majority ${ }^{12}$ cannot be implemented without the direct participation of political forces.

9 For instance, in Hungary, now in part also in the Republic of Armenia.

10 For instance, in the Russian Federation the mentioned body is called Constitutional Assembly.

11 Till 06.12.2015 constitutional amendments the RA Constitution could be adopted and amended just via a referendum. In the result of constitutional reforms the RA Constitution prescribed a possibility of amendment of certain constitutional regulations also by the National Assembly.

12 For instance, constitutional regulations concerning organization and activities of the state power bodies, fundamental human and citizen rights and freedoms. 
The presented legal regulations lead us to a conclusion that political forces have direct role with regard to the issues of both the adoption of constitutional amendments, and also of calling a referendum. This role is obvious also from the viewpoint of implementation of constitutional norms.

The circumstance should also be taken into account that in comparison with other institutions and groups, for political forces constitutional developments are primarily necessary for gaining and preserving power, as well as forming and developing a desirable model of separation and balance of powers, which becomes essential from the viewpoint of their whole role in the process of constitutional developments. Hence, it is obvious that three main factors determine the impetus for the mentioned forces: 1 . individual, private interests of the people, representing political forces ${ }^{13}, 2$. partisan interests ${ }^{14}, 3$. public interests. Taking into account the general aims of the activities of political parties, it is naturally impossible to exclude the existence and role of individual or partisan interests in the activities of these forces. Hence, it is obvious that in this context the key objective is to find a proper balance between the mentioned individual and partisan factors and the public interest in the aspect that individual and partisan interests should be secondary, derivative from the public interest and serve the main aim of social systems - the circumstance that the axis, basis of all the social systems is the human being as a highest value, for whom possibilities of self-expression and self-realization should be guaranteed via establishment and strengthening of the rule of law.

The following circumstance is also important in the mentioned context: if constitutional developments are implemented via making amendments to the text of the Constitution, the isolation of political forces, at first, the ruling political force from other political forces and society and the solitary search of constitutional solutions should be excluded during this, as the opposite process always leads to decline in confidence in constitutional regulations and their implementation, hence also, to the absence of constitutional stability. In this aspect the example of constitutional reforms in the South African Republic is interesting, the sucess of which, according to some authors, was conditioned not just by the circumstance of wide public participation, but also by the existence of «enogh inter-partisan consensus» ${ }^{15}$.

13 For instance, attempts of extension of term of office of presidents, which are rather widespread in recent years.

14 For instance, choice of concrete form of governance, concrete electoral system, etc., with the aim of preserving the role of a concrete political force in the system of state power.

15 See M. van Vliet, W. Wahiu, A. Magolowondo, Constitutional Reform ..., p. 12, https://openaccess.leidenuniv.nl/bitstream/handle/1887/30222/ASC-075287668-3333-01.pdf?sequence=1, (access: 16.06.2018). 
The above-mentioned leads us to a conclusion that the political environment has undeniable effect on the choice of constitutional solutions and their factual realization.

\section{Constitution as an Important Phenomenon for Defining the Rules of the Political Game}

In the discussed context we should take into consideration that the impact of politics on constitutional systems isn't unilateral, as the Constitution, in its turn, defines the rules, within the frames of which the state, hence, also the political power should act. From this viewpoint the statement of French prominent lawyer Pierre Sandevuar is interesting, according to which: "It is the politics, which formulates the law, but at the same time, the law itself responds to politics, introducing to it a regulating element and making political actors to act transparently, fairly and responsibly"16. The view expressed in literature, according to which fundamental social changes are possible only via such constitutional changes, which reflect corresponding changes of political culture directed to strengthening constitutionalism, respect towards human and citizen rights and the rule of law, is also interesting ${ }^{17}$.

Therefore, the stability of the Constitution and constitutional system is conditioned not just by this or that change of correlation of political forces, but generally, by the corresponding level of constitutional and political culture of the society. The latter predetermines not just the character of internal constitutional solutions, but also the external factors, having impact on their definition and viability, as well as the methods of reaction to them. It is not accidental that in literature the circumstance that a number of textual amendments are made to the Basic Law even in conditions of rigid constitutions, as for instance, in Germany, Czech Republic, India, South African Republic, is conditioned just by the impact of culture and politics. Whereas, the culture and politics of other states make textual amendments to the Constitution rather difficult or even impossible, for instance, in Italy and Spain ${ }^{18}$. From this viewpoint the approach expressed in literature, according to which the realization and stability of the Constitution depend on the circumstance how much it is accepted and preserved by the state power, and most importantly - by different social groups, is also worth mentioning ${ }^{19}$.

16 Seе П. Сандевуар, Введение в право, Москва 1994, р. 61-64.

17 See M. van Vliet, W. Wahiu, A. Magolowondo, Constitutional Reform..., p. 13.

18 See D. Oliver, C. Fusaro (eds.), How Constitutions Change..., p. 396-397.

19 See Inquiry to Review New Zealand's Existing Constitutional Arrangements, Report of the Constitutional Arrangements Committee, Presented to the House of Representatives, 
Hence, we believe that constitutional and political culture of the society has key significance for the existence of the feature of constitutional stability.

\section{The Common Aim of the Constitution and Politics and its Role for Ensuring the Constitutional Stability}

While differentiating constitutional policy from the ongoing politics, we should be guided by the logic that law and politics should have one main common aim regulation of social relations by guaranteeing the principle of rule of law. And in such conditions it becomes obvious that the Constitution should be not a tool for politics, but a bound, framework for it. Moreover, the constitutional developments should express not the current political preferences and interests, but be superior to them and define fundamental legal framework for political actors and events. In other words, constitutional policy should be clearly differentiated from the current politics, and the Constitution should be not a part of the ongoing political game, but should have a role of defining the rules of that game. It is not accidental that the term "Constitution" is itself etymologized also from the aspect of "limitation", clarification of the limits of power and of establishing "inescapable snare" for all of them, who will try to go out of their authorities prescribed by law ${ }^{20}$. It's worth mentioning in this context that according to various studies in all the situations, when political elites have been trying to use the Constitution with the aim to gain political dominance, the final result has been the paradox "Constitution without constitutionalism" 21 , which, to our mind, is unacceptable from the viewpoint of guaranteeing constitutional stability and stable democracy.

The next conclusion, which is important in this context, is the following: the Constitution should not be subject to amendment parallel to every change of political situation of the state or formation of a new political majority. The Constitution has a fundamental role from the aspect of regulating social relations and can't be used just as a tool for solving ongoing political problems. Moreover, the Constitution is not just a document with a highest legal force, but also a symbol of a concrete constitutional system, and from this viewpoint the Basic Law has a symbolic significance. Hence, the Constitution should in reality be perceived by society as a fundamental document, symbol of the constitutional

Forty-seventh Parliament (Hon Peter Dunne, Chairperson), August 2005, http://www.parliament.nz/NR/rdonlyres/575B1B52-5414-495A-9BAF-C9054195AF02/15160/DBSCH SCR_3229_2302.pdf, p. 7 (access: 04.02.2015).

20 See $\bar{G}$. Harutyunyan, Constitutional Culture: the Lessons of History and the Challenges of Time, Yerevan 2017, p. 22.

21 See M. van Vliet, W. Wahiu, A. Magolowondo, Constitutional Reform..., p. 12. 
system, should create a feeling of the factually existing constitutionalism, and not of a political declaration accidentally adopted or amended parallel to each political event. Hence, the frequency of constitutional amendments can't be conditioned just by the balance of political forces and its mathematical calculation. The ways of constitutional amendments and the process of their realization should form such a public perception that the Constitution is a stable document, symbol of a concrete constitutional system and cannot be amended just based on the political will of the political majority of the day. The opposite situation can make the proper realization of constitutional norms impossible and lead to distortion of values, underlying constitutional stability, as well as of such values, underlying the Rule-of-Law State, as predictability and legal certainty, excluding also the perception of the Constitution as a symbol of a concrete constitutional system.

The Venice Commission has continuously stated regarding the discussed issue that too frequent changes of the Constitution have negative impact from the viewpoint of constitutional and political stability ${ }^{22}$. Moreover, the Commission regrettably emphasized on the constitutional amendments in Croatia that during a very short timeframe 23 the Constitution was amended two times, not giving an opportunity to use the possibilities provided by the first amendment ${ }^{24}$.

\section{Conclusions}

Summarizing the implemented analysis, it should be noted that Constitution and politics should have one main common aim - regulation of social relations via guaranteeing the principle of rule of law. In such conditions it becomes obvious that the Constitution should be not a tool for politics, but a bound, framework for it. Moreover, the constitutional developments should express not the current political preferences and interests, but be superior to them and define fundamental legal framework for political actors and events. In other words, constitutional policy should be clearly differentiated from the current politics, and the Constitution should be not a part of the ongoing political game, but should have a role of defining the rules of that game. The Constitution should not be subject to amendment parallel to every change of political situation of the state or formation of

22 See CDL-AD(2010)001, Report on Constitutional Amendment, Adopted by the Venice Commission at its 81st Plenary Session (Venice, 11-12 December 2009), http://www. venice.coe.int/docs/2010/CDL-AD\%282010\%29001-e.pdf, (access: 20.01.2018).

23 The point is on 2000 and 2001 constitutional amendments.

24 See CDL-PI(2015)023, Compilation of Venice Commission Opinions concerning Constitutional Provisions for Amending the Constitution, European Commission for Democracy through Law (Venice Commission), Strasbourg, 22 December 2015, http://www.venice. coe.int/webforms/documents/?pdf=CDL-PI(2015)023-e, (access: 16.06.2018). 
a new political majority. The Basic Law has a fundamental role from the aspect of regulating social relations and can't be used just as a tool for solving ongoing political problems. It is a symbol of a concrete constitutional system, and should in reality be perceived as such.

\section{RÉSUMÉ}

The article considers the issues of differentiation of constitutional policy from ongoing politics. The author concludes that Constitution and politics should have one main common aim - regulation of social relations via guaranteeing the principle of rule of law. The Constitution should be not a tool for politics, but a bound, framework for it. Moreover, the constitutional developments should express not the current political preferences and interests, but be superior to them and define fundamental legal framework for political actors and events. In other words, constitutional policy should be clearly differentiated from the current politics, and the Constitution should be not a part of the ongoing political game, but should have a role of defining the rules of that game. The Constitution should not be subject to amendment parallel to every change of political situation of the state or formation of a new political majority. The Basic Law has a fundamental role from the aspect of regulating social relations and can't be used just as a tool for solving ongoing political problems. It is a symbol of a concrete constitutional system, and should in reality be perceived as such.

\section{Bibliography}

R. Calvert, Coordination and Constitutional Change, Washington University in St. Louis, http://calvert.wustl.edu/downloads/CoordConstChg.MPSA.pdf, (access: 15.04.2016).

M. Cerar, The Relationship Between Law and Politics, «Annual Survey of International \& Comparative Law» 2009, Volume 15, Issue 1.

CDL-AD(2010)001, Report on Constitutional Amendment, Adopted by the Venice Commission at its 81st Plenary Session (Venice, 11-12 December 2009), http://www.venice.coe.int/ docs/2010/CDL-AD\%282010\%29001-e.pdf, (access: 20.01.2018).

CDL-PI(2015)023, Compilation of Venice Commission Opinions concerning Constitutional Provisions for Amending the Constitution, European Commission for Democracy through Law (Venice Commission), Strasbourg, 22 December 2015, http://www.venice.coe.int/ webforms/documents/?pdf=CDL-PI(2015)023-e, (access: 16.06.2018).

G. Harutyunyan, Constitutional Culture: the Lessons of History and the Challenges of Time, Yerevan 2017.

D. Oliver, C. Fusaro (eds), How Constitutions Change (A Comparative Study), Oxford and Portland, Oregon 2011.

Inquiry to Review New Zealand's Existing Constitutional Arrangements, Report of the Constitutional Arrangements Committee, Presented to the House of Representatives, 
Forty-seventh Parliament (Hon Peter Dunne, Chairperson), August 2005, http://www.parliament.nz/NR/rdonlyres/575B1B52-5414-495A-9BAF-C9054195AF02/15160/DBSCH_ SCR_3229_2302.pdf, (access: 04.02.2015).

I. A. Kravets, Russian Constitutionalism: Problems of Formation, Development, and Implementation, St. Petersburg 2005.

G. L. Negretto, The Durability of Constitutions in Changing Environments: A Study on Constitutional Stability in Latin America, http://verfassungswandel.files.wordpress. com/2008/10/14-negretto-paper.pdf, (access: 15.04.2016).

P. Sandevoire, Introduction to the Law, Moscow 1994.

N. Vitruk, Constitutional Justice, Moscow 2005.

M. van Vliet, W. Wahiu, A. Magolowondo. Constitutional Reform Processes and Political Parties: Principles for Practice, https://openaccess.leidenuniv.nl/bitstream/handle/1887/30222/ ASC-075287668-3333-01.pdf?sequence=1, (access: 16.06.2018). 